\title{
EXPERIMENTAL STUDY ON PIPING FAILURE OF NATURAL DAM
}

\author{
Ripendra AWAL ${ }^{1}$, Hajime NAKAGAWA ${ }^{2}$, Kenji KAWAIKE ${ }^{3}$, Yasuyuki BABA ${ }^{4}$ and \\ Hao ZHANG 4
}

\author{
${ }^{1}$ Member of JSCE, Dr. of Eng., Research Fellow, Disaster Prevention Research Institute, Kyoto University \\ (Shimomisu, Yoko-oji, Fushimi-ku, Kyoto 612-8235, Japan) \\ ${ }^{2}$ Member of JSCE, Dr. of Eng., Professor, Disaster Prevention Research Institute, Kyoto University \\ (Shimomisu, Yoko-oji, Fushimi-ku, Kyoto 612-8235, Japan) \\ ${ }^{3}$ Member of JSCE, Dr. of Eng., Associate Professor, Disaster Prevention Research Institute, Kyoto University \\ (Shimomisu, Yoko-oji, Fushimi-ku, Kyoto 612-8235, Japan) \\ ${ }^{4}$ Member of JSCE, Dr. of Eng., Assistant Professor, Disaster Prevention Research Institute, Kyoto University \\ (Shimomisu, Yoko-oji, Fushimi-ku, Kyoto 612-8235, Japan)
}

\begin{abstract}
The failure of natural dam may occur with a variety of failure modes which includes overtopping, seepage or piping, sudden sliding etc. Natural dams may fail due to seepage or piping because they have not undergone systematic compaction and they may have high porosities. In-depth knowledge of the mechanism of the dam failures by seepage or piping and measured data are still lacking. Extensive laboratory experiments are carried out to study enlargement of the pipe due to internal erosion and resulting outflow hydrographs by varying size of initial pipe, lake water level, lake water volume, slope and location of the pipe. This paper highlights limitations of simplified models used to predict outflow hydrograph due to piping failure of the dam based on experimental results and provides data set for the validation of numerical model. Experimental results show that the initial size, slope and location of pipes have significant effects on magnitude and occurrence time of peak discharge.
\end{abstract}

Key Words : piping, internal erosion, natural dam, outflow hydrograph, laboratory experiment

\section{INTRODUCTION}

Natural dam such as landslide dam and moraine dam are made up of a heterogeneous mass of unconsolidated or poorly consolidated material. It differs from constructed embankment dam in that it has no water barrier, filter zones or drain zones and it also has no channelized spillway. Nearly all upstream and downstream faces of natural dams are at the angle of repose of the materials. The failure of natural dam may occur with a variety of failure modes which includes overtopping, seepage or piping, and sudden sliding etc. Awal et al. attempted to derive graphical relationships to predict failure modes of landslide dam (overtopping failure, instantaneous slip failure and progressive failure) by laboratory experiments in the flume ${ }^{1)}$. However these relationships are derived based on number of assumptions. The failure modes depend on rate of water level rise in the upstream reservoir (which depends on flow condition, dam size, characteristics of dam, volume and shape of the reservoir etc.) and strength of the dam body. Thus if inflow discharge is very low the possibility of failure by progressive failure is high. The experimental result shows that peak discharge produced by progressive failure is higher than other failure modes. Similarly the data set of embankment dam failure shows higher peak discharge produced by seepage or piping compared with overtopping for higher dam factor ${ }^{1}$. Therefore the study on seepage or piping failure of the dam is essential for the prediction of potential flood for flood risk assessment and management.

Natural dams may fail due to seepage or piping because they have not undergone systematic compaction and they may have high porosities ${ }^{2}$. This may cause seepage through the dam that could potentially lead to failure by internal erosion 


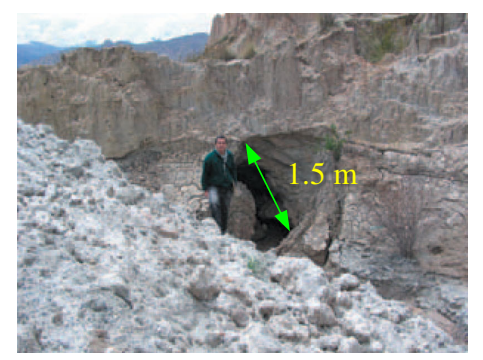

Fig. 1 Natural tunnel through a landslide dam in Allpacoma valley, La Paz, Bolivia, formed due to piping failure ${ }^{6}$.

(piping). Internal erosion of natural dam takes place when water that seeps through the dam carries soil particles away from the dam. If the seepage that discharges at the downstream side of the dam carries particles of soil, an elongated cavity or "pipe" may be eroded backward toward the natural lake through the dam or dam bed. When a backward-eroding pipe reaches the lake, a catastrophic breaching of the dam may occur.

Seeps occurred on the downstream face of many landslide dams. Several seepage points developed before overtopping of a recent landslide dam formed on $4^{\text {th }}$ January, 2010 in Hunza River at Attabad, Pakistan. Piping hole also developed in the downstream face of the Tangjiashan Barrier Dam, China in 20083). Piping and undermining caused the collapse of the landslide dam that impounded Lake Yashinkul in 19662). Some other landslide-dam failures in which seepage erosion probably was the major cause were the 1906 Cache Creek dam in northern California, the 1945 Cerro Condor-Sencca dam on the Mantaro River in Peru, and the 1973 Costantino dam on the Buonamico River of southern Italy ${ }^{4}$. The failure of Rio Toro landslide dam in Costa Rica in 1992 was due to retrogressive sliding caused by seepage and internal erosion ${ }^{5}$. Allpacoma Landslide Dam (see Fig. 1) in Bolivia failed due to piping and overtopping( ${ }^{6}$. A tunnel about $1.5 \mathrm{~m}$ in diameter formed through the dam about $2 \mathrm{~m}$ below the dam crest due to erosion.

In the case of moraine dam, self-destruction of a moraine dam may cause by the spontaneous failure of a well weathered dam slope and seepage from the networks of drainage conduits developed in the $\mathrm{dam}^{7}$. Size and shape of the conduits change from season to season and year after year by being frozen/ disappearing during the winter and being re-opened/ newly created during the summer. A small conduit grows to a large one due to erosion by water weakening the dam as a whole. Outburst of the glacial lake in Boqu River, China in 1981 was due to piping that appeared at $20-30 \mathrm{~m}$ below the water level in the base of the moraine dam which caused the sudden failure of moraine $\mathrm{dam}^{8}$.

Most of the dam break models used to predict flood hydrographs due to piping are based on simplified assumptions ${ }^{9), 10), 11), 12) . ~ F o r ~ e x a m p l e, ~ t h e ~}$ growth of zero sloped pipe is assumed uniformly along its length. In NWS BREACH model, it assumes that material above the pipe collapses when the water level in the reservoir falls below the top level of the pipe ${ }^{9}$. Some other model assumes that the vault of the pipe fails when the diameter of the pipe reaches $2 / 3$ of the dam height ${ }^{10)}$. Very few studies are focused on physical modeling of piping failure and resulting floods of embankment dams ${ }^{13), 14)}$. Internal erosion and piping failures in embankment dams have been described by Fell et al. (2001) as a four-phase process consisting of initiation, continuation, progression, and breach ${ }^{15}$ ) which is also applicable to natural dams. However this study focuses on piping failure (internal erosion) of natural dam with an assumption that a pipe leading from the upstream to the downstream face already exists. The physical processes involved in the piping failure are complex. In-depth knowledge of the mechanism of the dam failures by piping and measured data are still lacking. Extensive laboratory experiments are carried out to study enlargement of the pipe due to internal erosion and resulting outflow hydrographs by varying size of initial pipe, lake water level, lake water volume, slope and location of the pipe.

\section{EXPERIMENTAL METHODS}

The schematic diagram of the flume and other accessories used in the experiments are shown in Fig. 2. The rectangular flume of length $500 \mathrm{~cm}$, width $30 \mathrm{~cm}$ and depth $50 \mathrm{~cm}$ is used. The shape and size of the dam used in experiments for the flume slope of $5^{\circ}$ is shown in Fig. 2. In the case of the flume slope of $2.5^{\circ}$, the upstream and downstream slope lengths of the dam are $27.5 \mathrm{~cm}$ and $22.5 \mathrm{~cm}$ respectively. The height of all dams is $15 \mathrm{~cm}$.

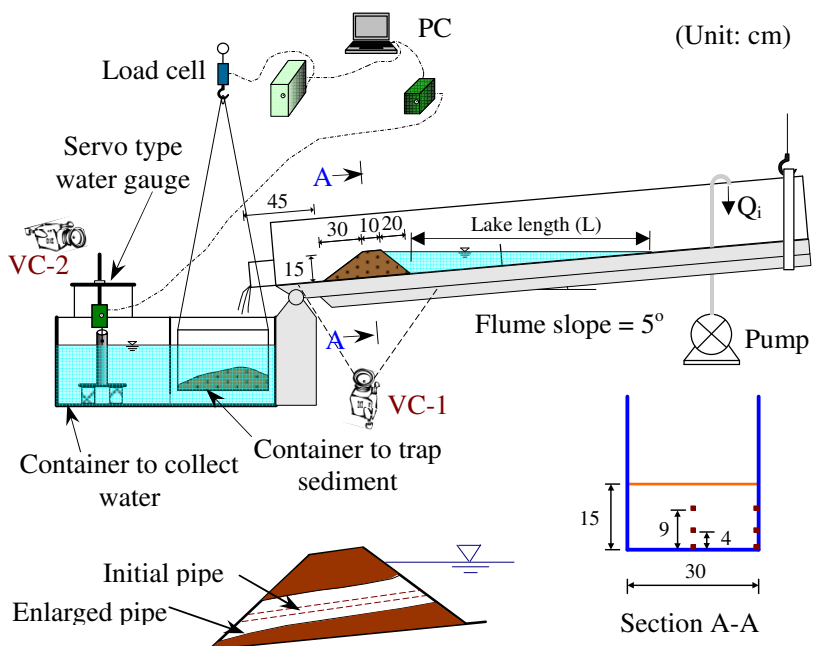

Typical longitudinal profile of pipe (Pipe at different location)

Fig. 2 Schematic diagram of the experimental setup. 


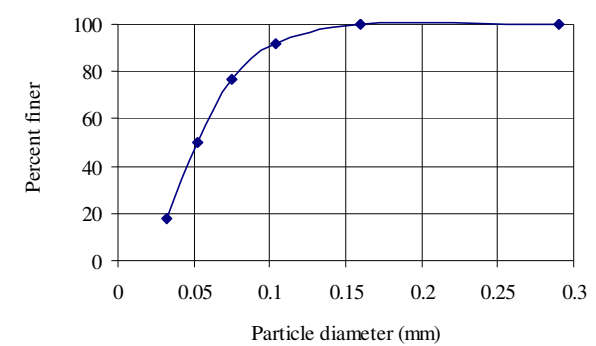

Fig. 3 Grain size distribution of sand used to prepare dam.

Table 1 Summary of experiments

\begin{tabular}{|c|c|c|c|c|c|c|}
\hline $\begin{array}{c}\text { Expt. } \\
\text { no. }\end{array}$ & $\begin{array}{c}\text { Channel } \\
\text { slope }\end{array}$ & $\begin{array}{l}1 \text { Initial size } \\
\text { of pipe } \\
(\mathrm{mm} \times \mathrm{mm})\end{array}$ & $\begin{array}{l}\text { Location of } \\
\text { pipe }\end{array}$ & $\begin{array}{c}\text { Water depth } \\
\text { at upstream } \\
\text { toe of dam } \\
(\mathrm{H}) \\
(\mathrm{cm})\end{array}$ & $\begin{array}{l}\text { Lake } \\
\text { length } \\
(\mathrm{L}) \\
(\mathrm{cm})\end{array}$ & $\begin{array}{c}\text { Lake } \\
\text { water } \\
\text { volume } \\
\left(\mathrm{cm}^{3}\right) \\
\end{array}$ \\
\hline 1 & 5 & $10 \times 10$ & Side-bottom & 12.5 & 60 & 21426 \\
\hline 2 & 5 & $10 \times 10$ & Side-bottom & 10 & 60 & 15626 \\
\hline 3 & 5 & $10 \times 10$ & Side-bottom & 7.5 & 60 & 10110 \\
\hline 4 & 5 & $7.5 \times 7.5$ & Side-bottom & 12.5 & 60 & 21426 \\
\hline 5 & 5 & $7.5 \times 7.5$ & Side-bottom & 10 & 60 & 15626 \\
\hline 6 & 5 & $7.5 \times 7.5$ & Side-bottom & 7.5 & 60 & 10110 \\
\hline 7 & 5 & $10 \times 10$ & Side-bottom & 12.5 & 143.4 & 30559 \\
\hline 8 & 5 & $10 \times 10$ & Side-bottom & 10 & 114.7 & 19558 \\
\hline 9 & 5 & $10 \times 10$ & Side- $4 \mathrm{~cm}$ up & 12.5 & 143.4 & 30559 \\
\hline 10 & 5 & $10 \times 10$ & Side- $4 \mathrm{~cm}$ up & 10 & 114.7 & 19558 \\
\hline 11 & 5 & $10 \times 10$ & Center-bottom & 12.5 & 143.4 & 30559 \\
\hline 12 & 5 & $10 \times 10$ & Center-bottom & 10 & 114.7 & 19558 \\
\hline 13 & 5 & $10 \times 10$ & Center-4cm up & 12.5 & 143.4 & 30559 \\
\hline 14 & 5 & $10 \times 10$ & Center- $4 \mathrm{~cm}$ up & 10 & 114.7 & 19558 \\
\hline 15 & 2.5 & $10 \times 10$ & Side-bottom & 12.5 & 286.6 & 57552 \\
\hline 16 & 2.5 & $10 \times 10$ & Side- $4 \mathrm{~cm}$ up & 12.5 & 286.6 & 57552 \\
\hline 17 & 2.5 & $10 \times 10$ & Side- $9 \mathrm{~cm}$ up & 12.5 & 286.6 & 57552 \\
\hline 18 & 2.5 & $10 \times 10$ & Center-bottom & 12.5 & 286.6 & 57552 \\
\hline 19 & 2.5 & $10 \times 10$ & Center-4cm up & 12.5 & 286.6 & 57552 \\
\hline 20. & 2.5 & $10 \times 10$ & Center- $9 \mathrm{~cm}$ up & 12.5 & 286.6 & 57552 \\
\hline
\end{tabular}

Note: Pipe size $10 \times 10 \mathrm{~mm}$ is Type: A and Pipe size $7.5 \times 7.5 \mathrm{~mm}$ is Type: B.

In order to form an eroded pipe the dam material must be strong enough to form a roof to keep the shape of the pipe. Dam material with sufficient fines content (\% finer than $0.075 \mathrm{~mm}>15 \%$ ) and partially saturated dams are favorable conditions for progression of erosion ability to support a roof ${ }^{16)}$. Silica sand of number $8\left(D_{50}=0.05 \mathrm{~mm}\right)$ was used to prepare the dam with different sized pipes in the flume. The particle size distribution curve of sand number 8 is shown in Fig. 3. Water was mixed with silica sand to make initial saturation of about $16 \%$ in all prepared dam. An artificial pipe was created in the dam body at the bottom, $4 \mathrm{~cm}$ up and $9 \mathrm{~cm}$ up from the flume bed at the center or side of the flume by using different square-shaped metal rods (see Fig. 2, Section A-A). After filling the upstream lake to the desired level, the inflow was stopped $\left(\mathrm{Q}_{\text {in }}=\right.$
$0)$. Then the steel rod was removed from the dam to initiate internal erosion of the pipe. The initiation stage of piping was not studied but attention was focused on growth of an initial pipe. In the beginning the pipe was enlarged due to erosion of the dam material in the pipe (see Fig. 2, Typical longitudinal profile of the pipe). The top part of the dam above the pipe may collapse or stable based on size of enlarged pipe, properties of the dam material and lake water volume. In the case of stable top, erosion of the pipe was occurred from bottom and sides when flow was changed to free surface flow.

Load cell and servo type water gauge were used to measure sediment and total flow in the downstream end of the flume. Two video cameras were used to capture enlargement of the pipe from side and front of the dam. The summary of experiments is shown in Table $\mathbf{1}$.

\section{RESULTS AND DISCUSSIONS}

Numbers of experiments were done to study internal erosion piping failure of natural dam and outflow hydrograph by varying water level in the upstream lake, initial size of the pipe, lake water volume, location of the pipe and pipe slope. In all experiments fine sediment is used to prepare dam, so the top part of the dam above the pipe is stable.

\section{(1) Effect of different lake water levels}

Fig. 4 shows the outflow hydrographs due to

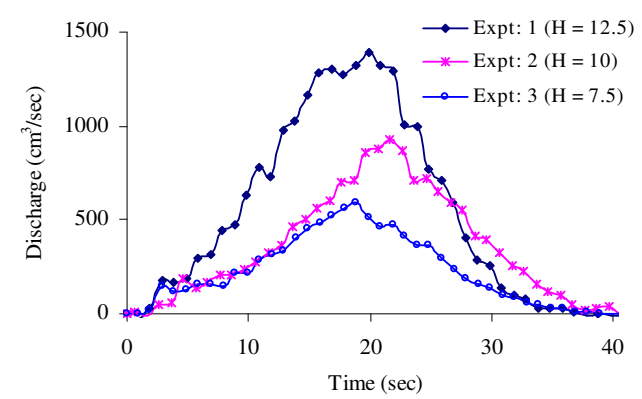

Fig. 4 Outflow hydrographs (Different lake water level).

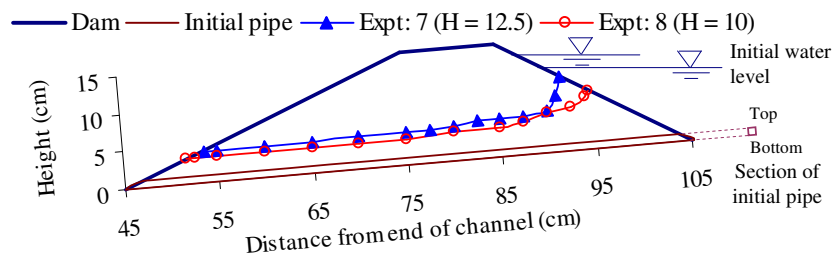

Fig. 5 Side view of final shape (top and bottom) of enlarged pipe.

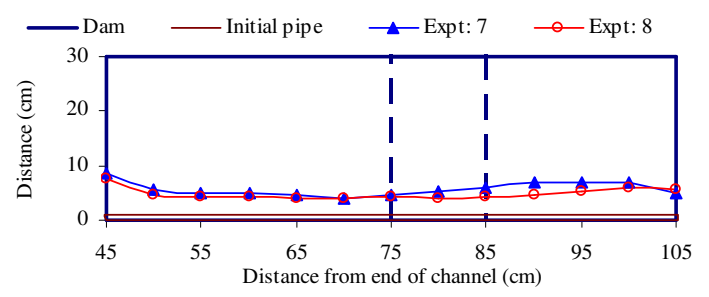

Fig. 6 Plan view of final shape of enlarged pipe and dam. 
piping under different lake water level. Flow through the pipe is directly proportional to hydrostatic head on the pipe, so the resulting peak discharge is higher for higher lake water level. The final shape of the enlarged pipe is bigger for higher lake water level in the lake as shown in Fig. $\mathbf{5}$ and Fig. 6. The enlargement of the pipe is not uniform along its length.

\section{(2) Effect of initial size of pipes}

Fig. 7 shows the outflow hydrographs due to piping under pipes with different initial sizes. The size of the pipe developed after flowing full water of the lake is slightly smaller than that in the case of initial pipe of Type B $(7.5 \times 7.5 \mathrm{~mm})$. Thus peak discharges produced by initial pipe size of Type B (Expt: 4 and 5) are also slightly lower than that produced by initial pipe size of Type A (Expt: 1 and 2). However, it takes more time to enlarge the pipe in the cases of initial pipe size of Type B, so time-to-peak is higher in these cases.

\section{(3) Effect of different lake water volumes}

Fig. 8 shows the outflow hydrographs due to piping under different lake water volume. For the same initial pipe size and lake water level the peak discharges produced by lakes with large lake water volume are higher than small lake water volume. The rate of drawdown in lakes with relatively large lake water volume for a given water level is slow compared with small lake water volume, which affects the enlargement of the pipe and peak discharge. The enlargement of the pipe in the upper part is bigger for large lake water volume as shown in Fig. 9 and Fig. 10.

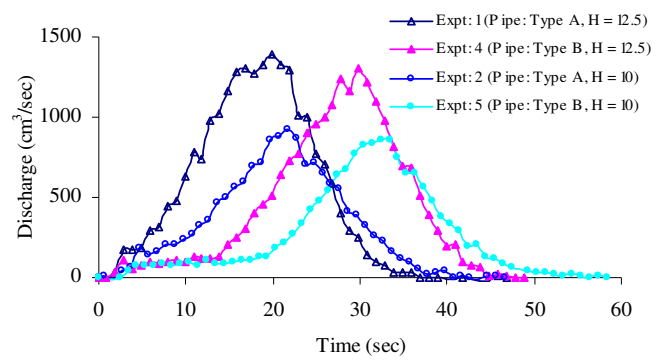

Fig. 7 Outflow hydrographs (Different initial sized pipe).

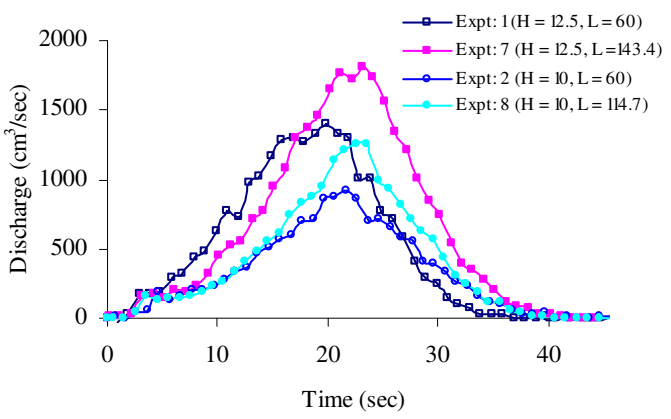

Fig. 8 Outflow hydrographs (Different lake water volume).

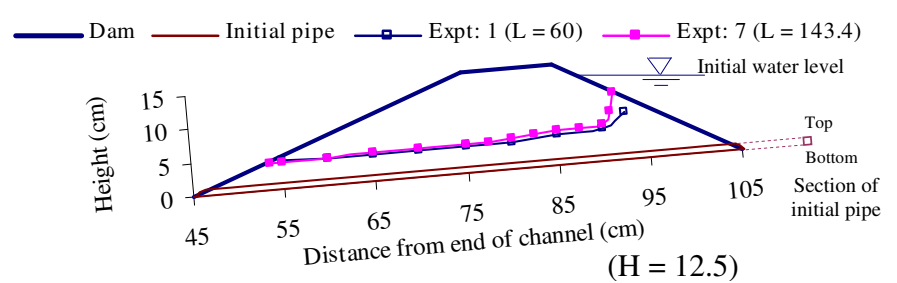

Fig. 9 Side view of final shape (top and bottom) of enlarged pipe.

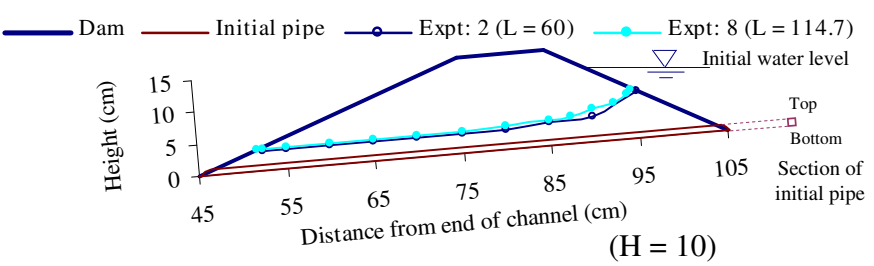

Fig. 10 Side view of final shape (top and bottom) of enlarged pipe.

\section{(4) Effect of different vertical location of pipes}

Expt: 15,16 and 17 were carried out with initial pipes at different level. The enlargement of the pipe and erosion of the dam at different time steps in three cases are shown in Fig. 11, Fig. 12 and Fig. 13. The failure processes in three cases were different. When the location of the pipe was at the bottom of the dam the failure was due to enlargement of the pipe. When the location of the pipe was at $4 \mathrm{~cm}$ up from the flume bed the failure

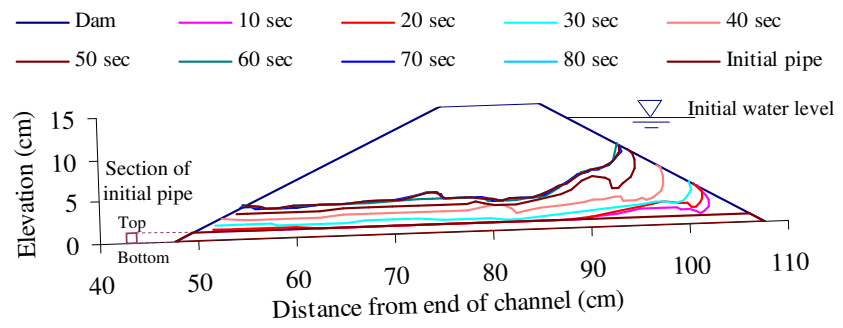

Fig. 11 Side view of temporal change (top and bottom) of the pipe at different time step (pipe at bottom) - Expt: 15 .

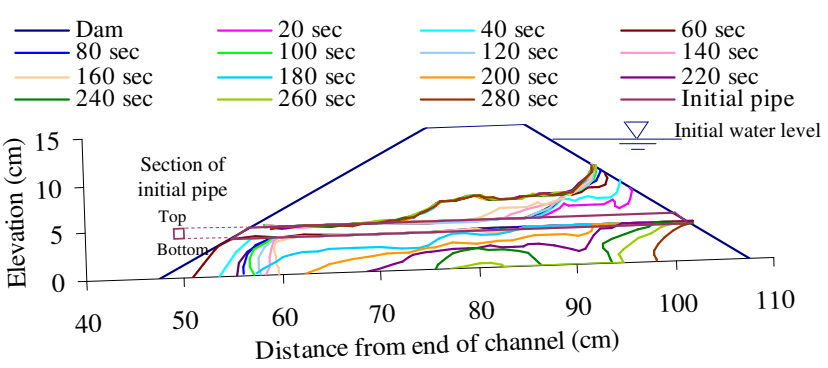

Fig. 12 Side view of temporal change (top and bottom) of the pipe at different time step (pipe at 4cm up) - Expt: 16.

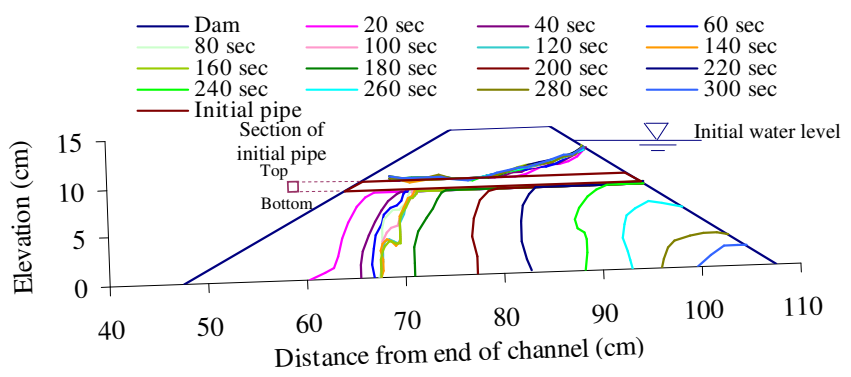

Fig. 13 Side view of temporal change (top and bottom) of the pipe at different time step (pipe at 9cm up) - Expt: 17 . 


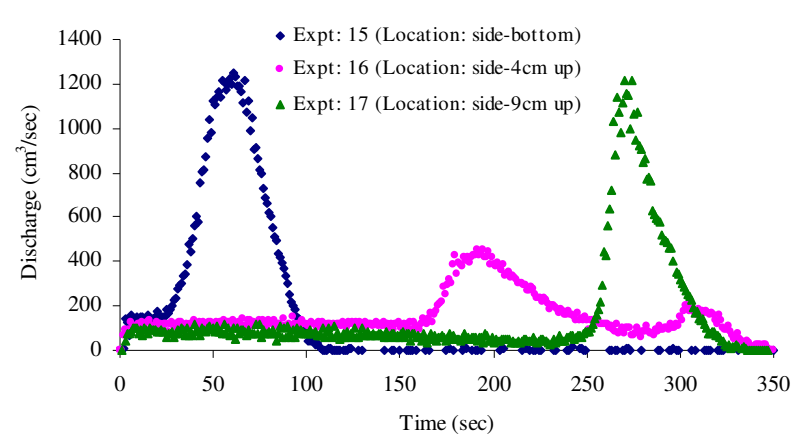

Fig. 14 Outflow hydrographs (Pipes at different vertical location).

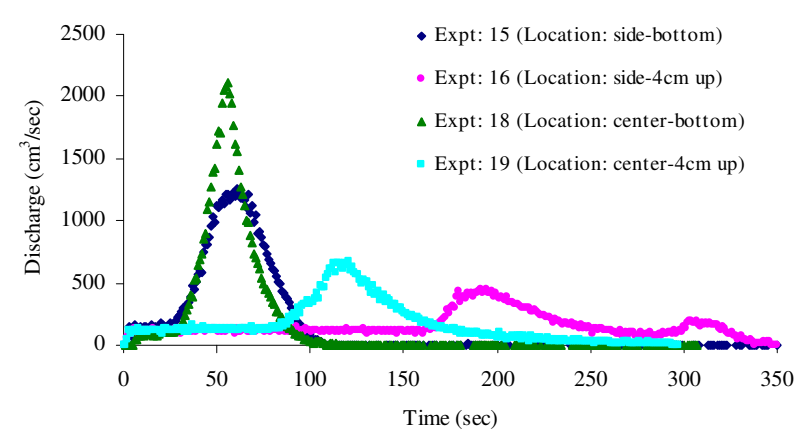

Fig. 15 Outflow hydrographs (Pipes at different lateral location).

was partly due to enlargement of the pipe and partly due to headcut erosion. Headcut erosion initiates at the outlet of the pipe and progress upstream internally during erosion process due to development and migration of headcut. Physical model test of large scale earthen embankment dam showed similar process before collapse of the top part of the dam above pipe ${ }^{14}$. When the location of initial pipe was at $9 \mathrm{~cm}$ up from the flume bed the hydrostatic head on the pipe was not sufficient to enlarge the pipe. In this case the dam was failed due to headcut erosion of the dam due to free surface flow. The erosion of downstream face proceeded upstream and big flood occurred when it reached near the lake water. Thus the shape of hydrograph, magnitude of peak discharge and time to peak are different according to location of pipes at different level as shown in Fig. 14.

\section{(5) Effect of different lateral location of pipes}

For the same lake water level, volume, initial pipe size and slope of the pipe the outflow hydrograph depends on different lateral location of the pipe as shown in Fig. 15. Peak discharge is higher when the pipe is located at the center of the dam where enlargement is possible in all sides for the pipe at the "center- $4 \mathrm{~cm}$ up" and three sides for the pipe at the "center-bottom". Location of the pipe significantly affect rate of the pipe enlargement and hence flood hydrograph. However, most of the existing models are based on assumption that enlargement will occur from all sides of the pipe.

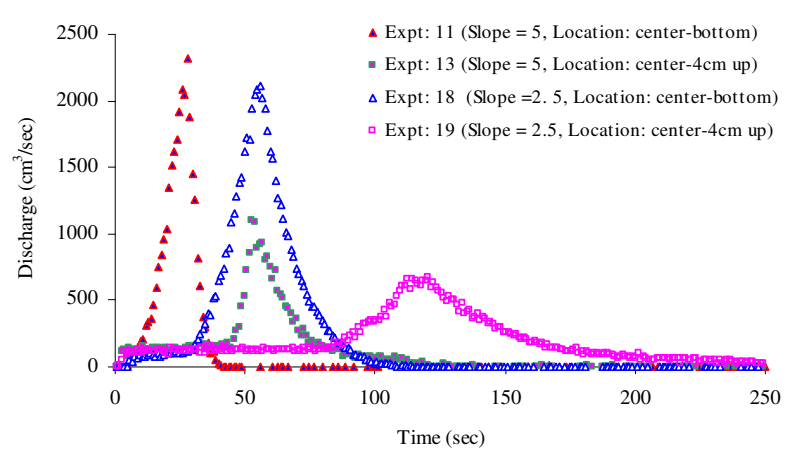

Fig. 16 Outflow hydrographs (Different pipe slope).

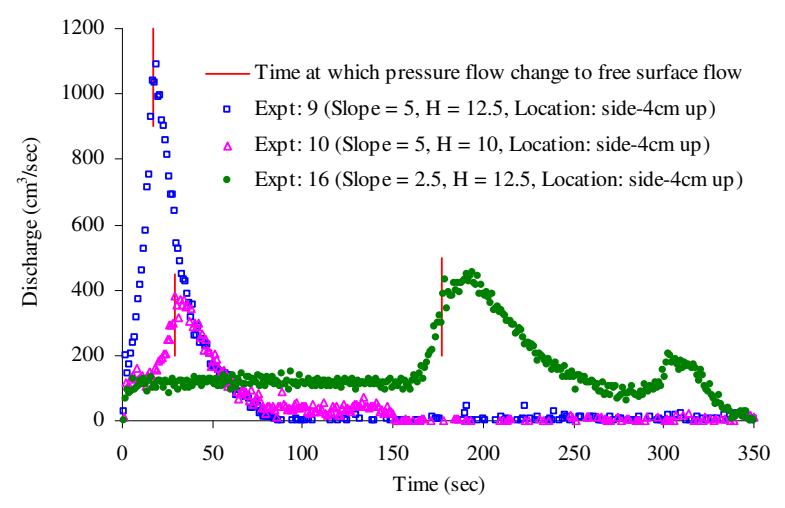

Fig. 17 Outflow hydrographs (Change in flow condition).

\section{(6) Effect of pipe slope}

In all experiments the initial slope of the pipe is parallel to the flume bed. Fig. 16 shows the comparison of outflow hydrographs for the pipe slope of $5^{\circ}$ and $2.5^{\circ}$. Enlargement of the pipe in the case of steeper flume/pipe slope is faster, so peak discharge occurred earlier and magnitude of peak discharge is also higher even if the volume of upstream lake water is smaller. The existing models assume zero sloped pipe, so these models will underestimate flood discharge if the slope of the pipe developed in the dam is steeper.

(7) Effect in outflow hydrograph after flow changes from pressure flow to free surface flow

When flow changes from pressure flow in the pipe to free surface flow the flow discharge may increase based on progress of seepage flow in the dam, headcut erosion and size of the enlarged pipe. As already explained, the enlargement of the pipe depends on hydrostatic head on the pipe and slope of the pipe. In Fig. 17 red line indicates the time at which flow changes from pressure flow to free surface flow in the pipe. Outflow hydrograph of Expt: 9 shows sudden decrease in flow discharge where as Expt: 10 and Expt: 16 show increasing trend of flow discharge for short time period. The simplified assumption of NWS BREACH model ${ }^{9)}$, collapse of remaining material of the dam body when flow changes from orifice control to weir-control, always produce decrease in flood 
discharge for short time period is not valid for the dam in which the remaining material of the dam body is stable.

\section{CONCLUSIONS}

Laboratory experiments were performed to study enlargement of piping and resulting outflow hydrograph. The outflow hydrographs due to piping failure of natural dam depends on lake water level, initial size of the pipe, lake water volume, slope and location of the pipe. For the same lake water level and volume, the size of the enlarged pipe and peak discharge is slightly lower in the case of smaller initial pipe size. However peak discharge occurred just after sufficient enlargement of the pipe, so there is time lag between occurrences of peak discharge in different sized pipes. For the same lake water level, same size and slope of the pipe the failure process depends on location of the pipe. Dam may fail by i) enlargement of piping, ii) enlargement of piping and headcut erosion and iii) headcut erosion based on location of the pipe at different level. Enlargement of the pipe in the case of steeper flume/pipe slope is faster, so the peak discharge occurred earlier and magnitude of the peak discharge is also higher even if the volume of upstream lake water is smaller for steeper slope.

Experimental results show non uniform enlargement of the pipe along its length, different magnitude and occurrence time of peak discharge for different initial size, location and slope of the pipe. Headcut erosion of the pipe occurs internally during the erosion process. The assumption of unrealistic failure of the material above the pipe may underestimate peak discharge if the remaining part of the dam is stable even if pressure flow in the pipe changed to free surface flow. For the improvement of model to predict outflow hydrograph due to piping failure of the dam we have to consider these phenomenons. The experimental results and data set will provide an opportunity to improve existing model to estimate flood hydrograph due to piping failure of natural dam.

The piping failure also depends on the strength of the dam material, so further study on different dam material and dam shape is essential to study the collapse of the top part of the dam above the pipe and resulting flood hydrograph.

ACKNOWLEDGMENT: This work was supported by the Japan Society for the Promotion of Science Postdoctoral Fellowship Program (grant-in-aid P 09080).

\section{REFERENCES}

1) Awal, R., Nakagawa, H., Kawaike, K., Baba, Y. and Zhang,
H.: Experimental study on prediction of failure mode of landslide dams, Proceedings of Fourth International Conference on Scour and Erosion (ICSE-4), pp. 655-660, 2008.

2) Schuster, R.L., and Costa, J.E.: A perspective on landslide dams, in Schuster, R.L., ed., Landslide Dams: Processes, Risk, and Mitigation: ASCE Geotechnical Special Publication No. 3, pp.1-20, 1986.

3) Liu, N., Zhang, J. X., Lin, W., Cheng, W. Y. and Chen Z. Y.: Draining Tangjiashan barrier lake after Wenchuan earthquake and the flood propagation after the dam break, Science in China Series E: Technological Sciences, Vol.52, No.4, pp.801-809, 2009.

4) Meyer, W., Schuster, R. L. and Sabol, M. A.: Potential for Seepage Erosion of Landslide Dam, Journal of Geotechnical Engineering, Vol.120, No.7, 1994.

5) Mora, S., Madrigal, C., Estrada, J. and Schuster, R.: The 1992 Rio Toro landslide dam, Costa Rica, Landslide News, Vol. 7, pp.19-21, 1993.

6) Hermanns, R.: All Clear for Allpacoma Landslide Dam, MAP: GAC Newsletter, Vol.5, No.1, 2005.

7) Yamada, T.: Glacier lake and its outburst flood in the Nepal Himalaya, Japanese Society of Snow and Ice, Data Centre for Glacier Research, Monograph No.1, 1998.

8) Xu, D.: Characteristics of debris flow caused by outburst of glacial lake in Boqu river, Xizang, China, 1981, GeoJournal, Vol.17(4), pp.569-580, 1988.

9) Fread, D. L.: BREACH: An erosion model for earthen dam failures, U.S. National Weather Service, Office of Hydrology, Silver Spring, Maryland, 1988 (revised 1991).

10) Paquier, A., Nogues, P. and Herledan, R.: Model of Piping in order to compute dam-break waves, in Morris, M. ed. CADAM - Concerted Action on Dambreak Modeling, Munich, Germany, 1998.

11) Loukola, E. and Huokuna, M.: A numerical erosion model for embankment dams failure and its use for risk assessment, in Morris, M. ed. CADAM - Concerted Action on Dambreak Modeling, Munich, Germany, 1998.

12) Mohamed, M., Samuels, P. G., Morris, M. W. and Ghataora, G. S. Improving the accuracy of prediction of breach formation through embankment dams and flood embankments, in Bousmar and Zech eds. Proceedings of the International Conference on Fluvial Hydraulics, River Flow 2002, Louvain-la-Neuve, Belgium, 2002.

13) Morris, M. W. and Hassan, M.A.A.M.: IMPACT: Breach formation technical report (WP2), IMPACT, 2005.

14) Hanson, G. J., Tejral, R. D., Hunt, S. L. and Temple, D. M.: Internal Erosion and Impact of Erosion Resistance, Collaborative Management of Integrated Watersheds, 30th Annual USSD Conference, pp.773-784, 2010.

15) Fell, R., Wan, C. F. Wan, Cyganiewicz, J. and Foster, M.: The time for development and detectability of internal erosion and piping in embankment dams and their foundations, UNICIV Rep. No. R-399, University of New South Wales, 2001.

16) Fell, R. and Foster, M.: The internal erosion and piping process, ASDSO-FEMA Workshop, 2000.

(Received September 30, 2010) 